\title{
Announcements
}

(C) The Author(s), under exclusive licence to Springer Nature B.V. part of Springer Nature 2021Published online: 28 February 2021

\footnotetext{
AIOSP - Association Internationale d'Orientation Scolaire et Professionnelle

IAEVG - International Association for Educational and Vocational Guidance

IVBBB - Internationale Vereinigung für Bildungs- und Berufsberatung

AIOEP - Asociación Internacional para la Orientación Educative Y Profesional
}

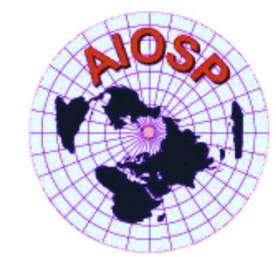

Founded in 1951

"Maximising the World's Potential through Guidance"

\section{What is IAEVG?}

The International Association for Educational and Vocational Guidance (IAEVG) is the worldwide counsellors' association and represents individuals as well as national and regional associations concerned with educational and vocational guidance on all continents. 


\section{The mission of IAEVG}

The aims of educational and vocational guidance are to assist students and adults in making their personal decisions about learning and work. This is achieved by helping people to:

- understand and appreciate their skills and abilities

- relate effectively with others

- explore career alternatives

- develop appropriate plans for educational and career management

- promote better vocational qualifications at all levels

- contribute to equal access for girls and women in education and work

- integrate successfully in society and the labour market

\section{The objectives of the Association are:}

- to promote and improve communication between people and organizations active in educational and vocational guidance

- to encourage the continuing professional development of ideas, practice and research in the field of guidance and counselling

- to collect and disseminate information on the latest educational and vocational guidance practice, study and research

\section{Benefits of membership of IAEVG}

As a member of IAEVG, you:

- belong to the only international association for careers and educational guidance practitioners and institutions

- will be sent three informative newsletters annually, published in English, French, Spanish and German

- access three editions of the refereed International Journal for Educational and Vocational Guidance

- have the opportunity to submit articles for publication in the professional journal and worldwide distribution

- can participate in international careers and guidance conferences around the world, learning about best practices, exchanging innovative ideas and building a rich international network

- can exercise your right to vote at the 4-yearly General Assembly of IAEVG

- become involved in special projects and/or interest groups

- can stand for election for a leadership position in the Association 


\section{How to become a member?}

To learn about the benefits of membership, see https:/iaevg.com/Membership\#Benefits.

To become a member of IAEVG or to renew your membership, simply proceed online at www.iaevg.com, by clicking on the IAEVG logo, then on "join us" and providing your information (even for renewal, as this is a new system). You can then make your electronic payment in US Dollar, Canadian Dollar, Euro or British Pounds.

All rates are based on fees in Euros: Individual members, $78 €$; Institutions, 100 $€$, Association fees depend on the number of members (https://iaevg.com/Membe rship\#Categories).

If necessary, please contact the IAEVG Administrative Coordinator (membership@iaevg.com).

IAEVG Website: www.iaevg.com

\section{Officers and Board of Directors}

President

Gert van Brussel, Netherlands

Président

Präsident

Presidente

Vice-Presidents

Guðbjörg Vilhjálmsdóttir, Iceland

Vice-Présidents

Jane Goodman, USA

Vizepräsidenten

Teruyuki Fujita, Japan

Vicepresidentes

Secretary General

Laurent Matte, Canada

Secrétaire général

Generalsekretärin

Secretario general

Treasurer $\quad$ Lydia Deyrem, France

Trésorière

Schatzmeister

Tesorero

\begin{tabular}{ll}
\hline Board of Directors & Peter Weber, Germany \\
Comité Exécutif & Jérôme Rossier, Switzerland \\
Exekutivausschuß & Gideon Arulmani, India \\
Junta Directiva & Soledad Romero Rodríguez \\
& Mary McMahon, Australia \\
& Gabriela Cabrera Lopez, Mexico \\
Co-opted non-executive & Ilze Jansone, Latvia \\
and non-voting member & Jean-Jacques Ruppert \\
of the Board of Directors & \\
\hline
\end{tabular}




\title{
Call for volunteers
}

\section{Are you a native speaker of German?}

The International Journal of Educational and Vocational Guidance is continually in need of volunteers to translate article abstracts. We are currently in need of additional volunteers who can translate English-language abstracts into German. Typically, volunteers translate one 100-word abstract once every month or two, for a total of less than 10 abstracts a year. In exchange for this valuable service to our scientific community, your name will be listed in our masthead and you will receive free access to the journal. We can also provide a testimonial letter about your involvement with the journal if needed. A degree of familiarity with the domain is needed, but translators who are at the stage of being a doctoral candidate are already welcome.

\section{Book announcement}

\section{From career to calling: a depth psychology guide to soul-making work in darkening times}

\author{
by Suzanne Cremen $\mathrm{PhD}$
}

ISBN 9780367444518

Published April 27, 2020 by Routledge

1st Edition, 212 Pages

'From Career to Calling: A Depth Psychology Guide to Soul-Making Work in Darkening Times' arrives at a time when we need it most. For many of us, the illusion of control over our lives has been cruelly shattered. While old ways no longer do, we have yet to work out how to move forward in an uncertain world. As Suzanne Cremen says in her preface 'Soul-making happens in the places where things fall apart'.

The promise of this book is that by examining both the conscious and unconscious elements of our lives, and the societies we live in, we can come into an understanding of our life's purpose. The book's structure provides a skilful guide into this deepening understanding of self. Its overview of conventional approaches to career development and psychological types is followed by discussion of soul, personal and cultural wounds, and how in embracing our fate-'it is here, in this place, in this time, that we are called to live our lives'-we can shift from career to calling. The author is generous both with her own life experience as well as that of several interviewees whose stories are threaded throughout the book.

This book calls for imagination and a symbolic ways of thinking, but it also weaves in practical tips and suggestions. Each chapter concludes with reflective exercises to be done alone, in a group, or with the guidance of a skilled practitioner. In this way, it invites us to walk in two worlds - that of practical day-to-day life and 
that of the soul. In navigating these two worlds, Suzanne Cremen tell us, we can build a life of richer, deeper meaning while honouring the needs of the world around us.

I commend this book for work with graduate students seeking to bring their talents into the world.

Briony Stocker

Graduate Development Manager (MBA)

Monash Business School

briony.stocker@monash.edu

\section{Book announcement}

Rayman, J. R., \& Gottfredson, G. D. (Eds.). (2020). My life with a theory: John L. Holland's autobiography and theory of careers. Broken Arrow, OK: National Career Development Association.

Why did Holland write an autobiography? "I have been daydreaming for a long time about writing a personal account of my research experience that would be helpful for students and new researchers. The ideas and topics were stimulated by the unexpected problems and tasks I encountered as an author of a theory of careers and as a developer of several related psychological devices.... This account is an attempt to document the subjective side of the discovery and developmental processes in research that psychological training neglects with its emphasis on research design and statistical analysis or on clinical practice." (quoted from Holland's Preface to his autobiography; Rayman \& Gottfredson, 2020, p. 40)

This book is available in the NCDA Career Resource Store at www.ncda.org

\section{Training Event}

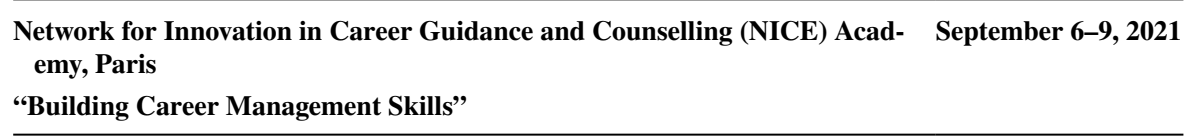

** Due to the COVID-19 pandemic, the NICE Academy has been postponed to September 2021. **

Please contact the organization if you wish to receive updates.

Theme of the third NICE Academy at the University of Paris:

Following Sultana (2012), career management skills can be defined as "a whole range of competences which provide structured ways for individuals and groups to gather, analyse, synthesise and organise self, educational and occupational information, as well as the skills to make and implement decisions and transitions" (p. 
229). They have become a key focus for implementing career educational programs and career competence-based curricula across EU countries. NICE (2016) attributes the professional role of Career Education to this important task and defines relevant competence standards for career practitioners.

When its educational component is forgotten or ignored, career guidance and counselling cannot unleash its full potential. By incorporating the promotion of career management skills in our practice, we can empower people to master their career-related challenges autonomously; we can support them in attaining more control over their career development; in becoming more independent.

And we need to do so. While globalization and innovation bring many benefits, they also challenge people to engage in lifelong learning. Organizations, too, are under continuous pressure to adapt, with many of them become less hierarchic, smaller, and more flexible. In this kind of an environment, citizens' ability to manage their own career development becomes crucial. We need to prepare people to deal with career-related challenges across their lifetime, not only at the beginning of their careers. For this purpose, we need to support citizens' learning and development of career management skills. However, many questions arise with this realization:

- What are the career management skills that actually support clients in mastering their career development? How do we know that they work?

- Does everybody need the same set of career management skills? Or are there meaningful differences between national contexts, labor markets...?

- How can career professionals effectively support clients in developing their career management skills? What approaches work? Why? And what if time is extremely limited?

- How and why should we assess career management skills? What techniques and tools are there?

- How can career professionals work together with educational bodies to promote career management skills? How could the role of career professionals evolve in the future?

- Are there any risks attached to the promotion of career management skills? Could we be misleading clients in the long run? Could the promotion of career management skills damage our profession?

- How can career practitioners be trained to build citizens' career management skills at schools, universities and through further education? What knowledge, skills and competences are needed? How can they be developed?

These are the sorts of questions that the third NICE Academy in Paris will focus on. Through interactive keynote lectures, various training workshops to choose from, presentations of innovative approaches and important research findings, and various networking activities, we hope to foster a meaningful exchange of knowledge about the promotion of career management skills and career education.

For more information, please visit www.nice-network.eu 


\section{Training event}

Applications are open for the 8th European Doctoral Programme in Career Guidance and Counselling (ECADOC) Summer School for doctoral students in career guidance and counselling. The Summer School, open to 20 current doctoral researchers, will be hosted by Associate Professor Peter Robertson at the School of Applied Sciences at Edinburgh Napier University. The event is sponsored by Skills Development Scotland (SDS). Tutors will include Professor Mary McMahon (University of Queensland), Professor Rie Thomsen (Aarhus University), Professor Tristram Hooley (University of Derby), and Dr Julia Yates (City University).

Important dates:

- Decision regarding event format—online or on campus: February 26th 2021

- Registration Deadline: March 26th 2021

Documents for application, to be submitted to Pete Robertson via email: p.robertson@napier.ac.uk

- A completed application form

- A CV in English

- A description of your doctoral research project, illustrating its relevance to the field of career

guidance and counselling (1-2 pages)

- A certificate of enrolment as a PhD student (scanned copy) or other verification

There is no fee for participating at the summer school. However, all participants will need to cover their own travelling and accommodation costs if the event is delivered on campus. We advise eligible participants to apply for Erasmus mobility funding as soon as possible and will support other relevant mobility agreements. Please do not book travel and accommodation prior to the announcement at the end of February.

Further information can be found at: http://www.larios.fisppa.unipd.it/ecadoc/ 


\section{Training event}

Combined ECADOC Summer School \& NICE Academy, Kosovo

August 30-September 4, 2022 "Social Emotional Learning and Career Guidance and Counselling"

ECADOC and NICE will organize a combined ECADOC Summer School \& NICE Academy in Pristina, Kosovo, hosted by the Universum College. Chaired by Lea Ferrari, Scott Solberg, and Johannes Katsarov, together focused on the theme of "Social Emotional Learning and Career Guidance and Counselling". The ambition is to share and discuss the newest insights and developments on the role of social and emotional competences in career development and career support and to build bridges between practice and research.

The ECADOC Summer School will begin on August 30, offering up to 25 doctoral researchers the opportunity to share and discuss their work in the field of career guidance and counselling and to become a member of our international research community. On September 1, the NICE Academy will begin, offering a series of keynote lectures, training workshops, and networking activities on the theme of the event to career professionals, academic trainers, interested researchers, and other career specialists. The summer school and academy will both continue until Saturday. All participants-practitioners, researchers, trainers, and others-will be able to select from diverse learning activities that belong to the shared program-including social events.

For more information, please visit www.nice-network.eu

\section{Conference}

"Maximizing Potential of Career Guidance"

The Riga conference is intended to be a live face-to-face event, insofar as national, European and international health and safety regulations allow. The final date will be determined soon. Please visit https://iaevgconference2020.lv/ for updates.

We hope to welcome you in Riga, Latvia in 2021 for the 44th IAEVG international conference, for three inspiring days exploring how career guidance can maximize the potential of individuals and communities, education and economies.

For a career guidance professional-whether you are a practitioner, trainer, researcher, manager or policy maker-the IAEVG conference is a supportive environment to develop new vision. This international forum has been created to reimagine the future of guidance as a discipline, field and a scope of practice. 
Come share and discover research and experience, deliver and take part in presentations and workshops, recharge your intellectual and emotional batteries. Together through professional and scientific exchanges we can rise as a community of practice to meet the challenges of contemporary society.

Join the IAEVG symposium where you can be part of the international dialog on investing in career guidance and teenagers' career aspirations. Learn about and contribute ideas on the evidence base for guidance, evaluation of guidance and advocacy for guidance. Share good practices, challenges and solutions.

Details on conference registration, including fees, deadlines and options for submitting contributions can be found at the conference website: https://iaevgconfe rence2020.1v/.

The conference is co-funded with support from the Erasmus+ programme, the European Social Fund SO 8.3.5. Project and the budget of the State Education Development Agency.

\section{References}

NICE. (2016). European Competence Standards for the Academic Training of Career Practitioners. Opladen: Barbara Budrich.

Sultana, R. G. (2012). Learning career management skills in Europe: A critical review. Journal of Education and Work, 25(2), 225-248. https://doi.org/10.1080/13639080.2010.547846.

Publisher's Note Springer Nature remains neutral with regard to jurisdictional claims in published maps and institutional affiliations. 